\title{
Tree Species Composition, Structure, and Aboveground Wood Biomass of a Riparian Forest of the Lower Miranda River, Southern Pantanal, Brazil
}

\author{
Florian Wittmann • Bianca Thaís Zorzi • \\ Fernando Augusto Tambelini Tizianel • \\ Marcus Vinicius Santiago Urquiza • \\ Rogério Rodrigues Faria • \\ Nathália Machado e Sousa • \\ Érica de Souza Módena • \\ Roberto Macedo Gamarra • \\ Augusto Lisboa Martins Rosa
}

(C) The Author(s) 2008. This article is published with open access at Springerlink.com

\begin{abstract}
The aboveground wood biomass (AWB) of tropical forests plays an important role in the global carbon cycle, and local AWB estimates provide essential data that enable the extrapolation of biomass stocks to ecosystem or biome-wide carbon cycle modelling. Few AWB estimates exist in Neotropical freshwater floodplains, where tree species distribution and forest structure depend on the height and duration of periodic inundations. We investigated tree species composition, forest structure, wood specific gravity, and AWB of trees $\geq 10 \mathrm{~cm}$ dbh in 16 plots totalling an area of 1 ha in a seasonally inundated riparian forest of the lower Miranda River, southern Pantanal, Brazil. The 443 tree individuals belonged to 46 species. Four species (Inga vera, Ocotea suaveolens, Tabebuia heptaphylla and Cecropia pachystachya) comprised more than $50 \%$ of the Total Importance Values (TIV), and floristic similarities between the plots averaged 38\%. Although we detected an overall increase in species diversity correlated with decreasing flood levels, the most important tree species had almost identical distribution patterns
\end{abstract}

\footnotetext{
F. Wittmann $(\bowtie)$

Biogeochemistry Department, Max-Planck-Institute for Chemistry, Becherweg 27,

55128 Mainz, Germany

e-mail: F-Wittmann@web.de

e-mail: wittmann@mpch-mainz.mpg.de

B. T. Zorzi • F. A. T. Tizianel • M. V. S. Urquiza • R. R. Faria • N. M. e Sousa •É. d. S. Módena •

R. M. Gamarra • A. L. M. Rosa

Ecology and Conservation, Universidade Federal de Mato Grosso do Sul (UFMS),

Campo Grande, Brazil
} 
along the flooding gradient. The stand basal area per plot $( \pm$ s.d.) amounted to $3.0 \pm$ $1.1 \mathrm{~m}^{2}\left(47.8 \pm 18.1 \mathrm{~m}^{2} / \mathrm{ha}\right)$, and the tree heights averaged $10.9 \pm 1.4 \mathrm{~m}$. Multiplying the individual basal areas by individual tree heights and a form factor of 0.6 , we estimated the aboveground wood volume (AWV) for each individual, and for each plot $\left(24.4 \pm 11.7 \mathrm{~m}^{3}, 391.1 \pm 188 \mathrm{~m}^{3} / \mathrm{ha}\right)$. Wood specific gravity (SG) varied between $0.39 \mathrm{~g} / \mathrm{cm}^{3}$ (Cecropia pachystachya) and $0.87 \mathrm{~g} / \mathrm{cm}^{3}$ (Tabebuia heptaphylla), with a stand level average of $0.63 \pm 0.12 \mathrm{~g} / \mathrm{cm}^{3}$. Multiplying the individual AWV with species SG, we estimated the plot AWB to be $16.2 \pm 6.4 \mathrm{Mg}(259.4 \pm 102 \mathrm{Mg} / \mathrm{ha})$. This value is comparable to that reported for late-successional forest stands of Amazonian floodplain forests, and it is close to the worldwide tropical average AWB. Because tree heights in the present forest were comparatively low when compared to other Neotropical forests, we found that resprouting of stems accounted for comparatively high basal areas. We argue that stem resprouting is an adaptation of tree species originating in non-flooded Cerrado to the seasonal inundations of riparian forests.

Keywords Aboveground wood volume · Flooding gradient . Floodplain forest . Pantanal $\cdot$ Resprouting $\cdot$ Species distribution $\cdot$ Wood specific gravity

\section{Introduction}

Seasonal inundation of roots and aboveground organs reduces oxygen availability to trees and thus is widely considered as a potential stress factor (Joly 1991). Trees subjected to periodic flooding often compensate anaerobic soil conditions by developing morpho-anatomical adaptations and by reducing metabolism during the waterlogged period, resulting in decreased photosynthetic rates, leaf shedding, and reduced wood growth and/or cambial dormancy (Fernandez et al. 1999; Parolin et al. 2004; Worbes 1997). Inundation is thus a powerful factor selecting the occurrence and distribution of tree species (Jackson and Colmer 2005), which in turn influences structure and biomass of seasonally flooded tree species communities.

In seasonally flooded Neotropical forests, richness and composition of arboreal comunities vary along the flooding gradient with its associated geomorphologic and pedologic variables, e.g., in the Orinoco basin (Godoy et al. 1999), in Amazonian floodplain forests (Ferreira 1997; Wittmann et al. 2006a), and in riparian forests of Neotropical savanna (e.g., Cerrado) regions (Oliveira-Filho et al. 1994; Metzger et al. 1997; Veneklaas et al. 2005). Structure and biomass of these forests is linked to the topographic position of forest stands and varies as a function of site colonization, stand age (forest succession) and frequency of natural habitat disturbance (Salo et al. 1986; Terborgh and Petren 1991; Worbes et al. 1992).

The Pantanal is a seasonal wetland that is located in the depression of the upper Paraguay River. It covers approximately $160,000 \mathrm{~km}^{2}$. Due to the Pantanal's heterogeneous geomorphology formed by spreadings, depressions, relict dunes, inselbergs, and differently-aged alluvial deposits, it is composed of a patchwork of both, seasonally inundated and non-inundated habitats (Sarmiento and Monasterio 1975; Zeilhofer and Schessl 1999). The seasonally inundated vegetation consists of 
grasslands and different forest types. Studies on the floristic composition of seasonally inundated forests within the Pantanal were performed, for example, by Prance and Schaller (1982), Pott and Pott (1994), Nunes da Cunha and Junk (2001), and Damasceno et al. (2005). Periodically inundated forests within the Pantanal are often mono-dominant, or composed of a few co-dominant species (Pott and Pott 1994). Riparian forests, which accompany the main rivers and the secondary riverchannels, were described as the most species-rich inundation forests within the Pantanal (Pott and Pott 1994; Damasceno et al. 2005).

Riparian forests are important landscape units in savanna regions because they consist of both flood-resistant species and immigrants from the adjacent uplands, thereby comprising most of the regional floristic biodiversity (Pither and Kellman 2002). In addition, they offer food and shelter for the terrestrial and aquatic fauna, therefore being recognized as areas with permanent conservation status by the Brazilian environmental legislation. Within the Pantanal, riparian forests are concentrated along the Paraguay River and its major tributaries. Combining the phyto-physiognomic vegetation classification proposed by the IBGE (1992) with remote-sensing data, Silva et al. (2000) calculated the spatial coverage of riparian forests within the Pantanal as approximately $2.4 \%$ of the landscape $\left(3,360 \mathrm{~km}^{2}\right)$.

There are comparatively few studies investigating tree species richness and distribution along the flooding gradient in the Pantanal, and investigations focusing on structure and biomass are scarce. However, the biomass of tropical forests plays an important role in the global carbon cycle, both as a reservoir of carbon and as a source of greenhouse gas emissions from deforestation (Fearnside 1997; Mahli et al. 2006). Nunes da Cunha and Junk (2001) investigated the distribution of woody plant communities in the northern part of the Pantanal near the city of Poconé in terms of habitat preference and found approximately 40 flood-resistant tree species, most of them showing a wide distribution range on the topographic gradient, from areas with prolonged flooding to dry habitats that become flooded only during extreme flood events. Damasceno et al. (2005) found 29 flood-resistant tree species $\geq 10.0 \mathrm{~cm}$ dbh (diameter at breast height) in seasonally inundated riparian forests of the Paraguay River near Corumbá in an area totalling 1.08 ha. The species associations of these flood-resistant species is clearly linked to the position of trees along the flooding gradient. Haase and Haase (1995) investigated the aboveground biomass of four invasive shrub and tree species in the Pantanal, to test for different allometric equations, but not with reference to abiotic variables. To the best of our knowledge no further studies investigating the impact of flood length and duration on tree species composition, structure, and biomass in the Pantanal have been done.

The present study investigates floristic composition, forest structure, and AWB of a seasonally inundated riparian forest of the Miranda River, southern Pantanal, Mato Grosso do Sul, Brazil. This study aims to analyze whether species composition and diversity depends on the topographic position of individual tree species, and if differences in forest structure and AWB along the flooding gradient can be observed. Additionally, this study provides the first AWB estimate of a seasonally inundated forest stand within the Pantanal, and therefore represents an important contribution to regional or ecosystem-wide carbon cycle models. 


\section{Methods}

\section{Study Site}

The present study was performed on the lower Miranda river $\left(19^{\circ} 34^{\prime} \mathrm{S}, 57^{\circ} 01^{\prime} \mathrm{W}\right)$, near the field station of the Universidade Federal de Mato Grosso do Sul (UFMS), southeastern Pantanal, Brazil (Fig. 1). The climate in the southern Pantanal is characterized by a pronounced dry season from May to September and a rainy season from October to April. Annual precipitation near Corumbá amounts to approximately 1,090 $\mathrm{mm}$ (Hamilton et al. 1996); mean annual temperatures range between $21^{\circ} \mathrm{C}$ in December and $27^{\circ} \mathrm{C}$ in July.

\section{Inventories}

Sixteen $25 \times 25 \mathrm{~m}\left(625 \mathrm{~m}^{2}\right)$ plots in riparian forests of the Miranda river were established in April 2007, totalling an inventoried area of 1 ha (Fig. 1). Seven plots were placed on the left and nine plots on the right side of the river. All plots were established close to the river bank, with a minimum distance of $50 \mathrm{~m}$ between them. Plot location was restricted to areas where forest patches extended more than $25 \mathrm{~m}$ inland of the river channel.

All trees $\geq 10 \mathrm{~cm}$ dbh were labelled, numbered, and measured in diameter (dbh). The heights of all trees were determined using a clinometer (Suunto, Vaanta, Finland). Species were identified in the field, and when this was not possible,

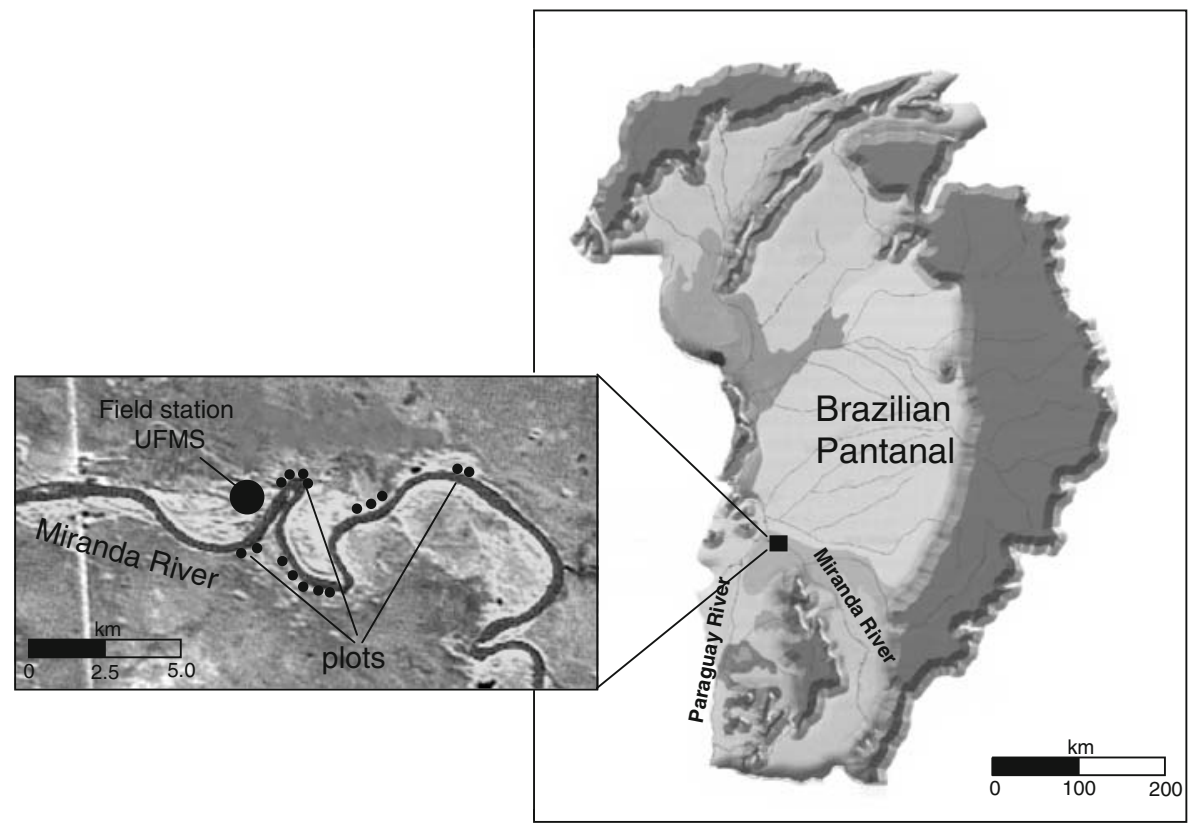

Fig. 1 Location of the study plots within the Brazilian Pantanal. Large map modified from WWF-Brazil (http://www.wwf.org.br), small map from CBERS-2 (05/09/2006, 166/122, Instituto Nacional de Pesquisas Espaciais - INPE, Brazil) 
identified provisionally as morpho-species with voucher specimens collected for later identification. The position ( $\mathrm{x}$ - and $\mathrm{y}$-coordinates) of single trees within the plots was measured using the distance along the river bank as the $\mathrm{x}$-axis, and that running inland as the y-axis. The position of trees above water levels was estimated using maximum flood marks of the last inundation (March 2006) on trunks relative to the water level of the Ladário gauge at the Paraguay River, which is located approximately $100 \mathrm{~km}$ from the study site. For the relationship of flooding and the species composition, we estimated the mean flooded period of all trees at our study site (days/year) for 1988-2006. Unfortunately, there are no water-level records at the Miranda River. As a tributary of the Paraguay River, the Miranda River is possibly characterized by an individual flooding regime. Maximum water levels at the Ladário gauge normally occur between May-June, those of the upper Miranda River earlier between February and March (Adámoli 1986). We presume, however, that even with different periods of highest water levels, positive relationships exist between the flooding regimes of both river basins because rainfall variability between the catchment areas amounts to less than $200 \mathrm{~mm}$ (Junk et al. 2006).

Wood samples of three individuals of each of the 15 most abundant tree species were made at breast height with an increment borer with a sharpened point (inner diameter $5 \mathrm{~mm}$, Haglöf Inc., Sweden). Samples of $1 \mathrm{~cm}$ length were taken from different sections of the wood cores using a caliper rule with $0.1 \mathrm{~mm}$ accuracy. The samples' fresh volume was estimated multiplying their length by diameter. Mean wood specific gravity (SG) of each species was calculated after $72 \mathrm{~h}$ of oven drying the samples at a temperature of $105^{\circ} \mathrm{C}$ as the ratio between dry weight and volume of the green wood (Fearnside 1997; Nogueira et al. 2005; Wittmann et al. 2006b). Intraindividual and intraspecific wood density variations were not considered in this study. All values are given with standard deviation (s.d.).

\section{Data Analysis}

Phyto-sociological studies include the determination of tree species richness per plot, the Total Importance Value (TIV, Curtis and McIntosh 1951, Table 1), the determination of species diversity (Shannon and Weaver 1949, $D=-\Sigma p_{i} \ln p_{i}$; where $p_{i}=n_{i} / N ; n_{i}=$ number of individuals within a species, $N=$ total number of individuals), and the determination of floristic similarity (Sørensen 1948, IS $=2 a(2 a+b+c)^{-1}$; where $a=$ number of species common to both plots, $b$ and $c=$ number of species unique to plot 1 and 2). To investigate the relationships between species occurrence and inundation height, each individual was entered into a three-dimensional coordinate system (position: $\mathrm{x}, \mathrm{y}$; height: $\mathrm{z}$ ), based on Triangulated Irregular Network - TIN (Digital Elevation Model, SURFER Version 5.00, Golden Software). Furthermore, the variation of the species composition was examined as a function of distance to the river bank (forest border effect). For each species, the Mean spatial Distribution Center (MDC; Ebdon 1998) was determined, as a result of the mean inundation and the mean distance to the forest border of all individuals present.

The AWB for species and plots was estimated as a function of the individual aboveground wood volume $\left(A W V=B * H^{*} F\right)$ multiplied by SG; where $B=$ basal area, $H=$ tree height, and $F=$ form factor of 0.6 , taking into account biomass losses of the aboveground wood due to ramifications in the canopy (Cannell 1984; Brown 


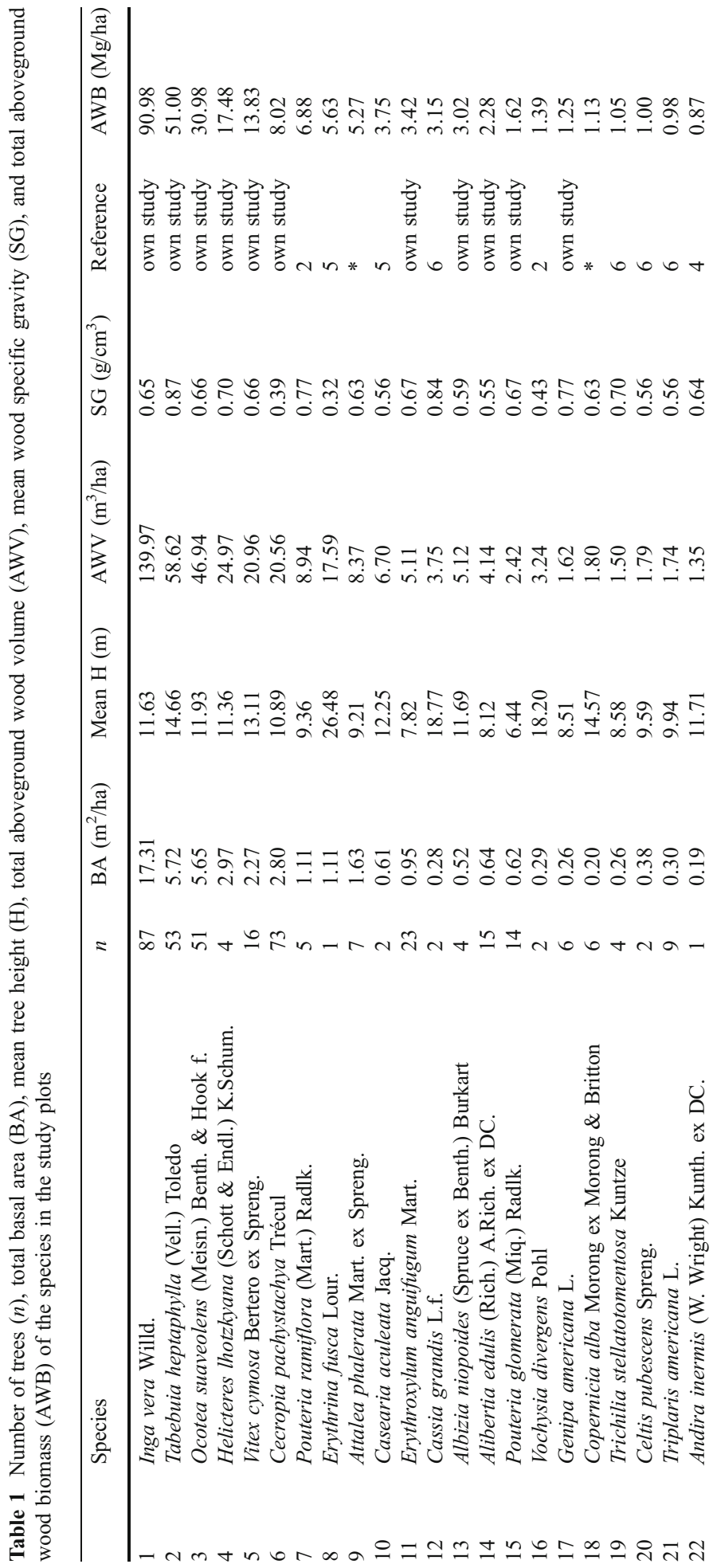




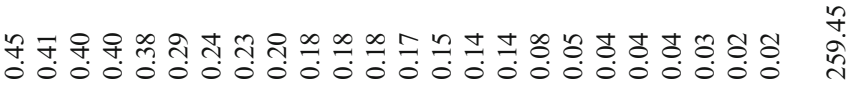

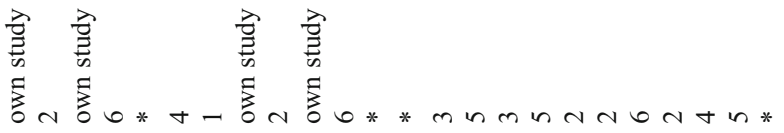

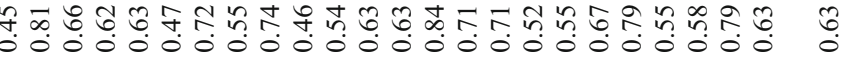

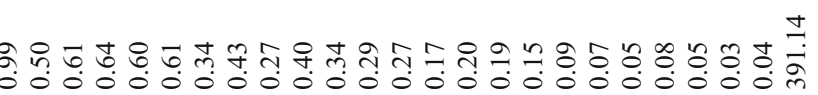

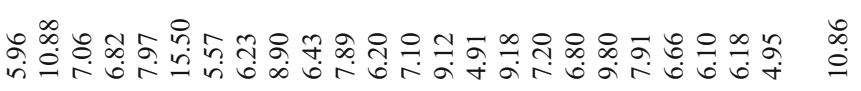

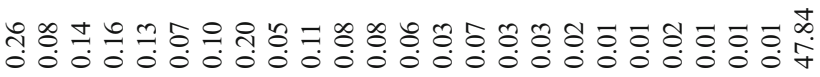

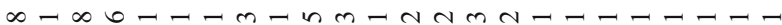

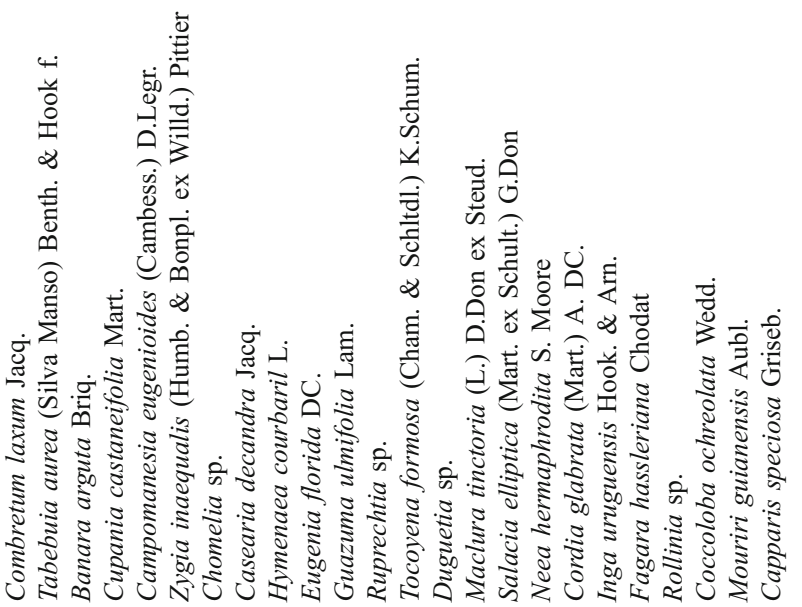

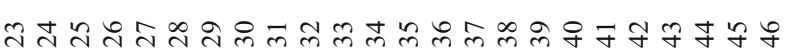


1997; Chave et al. 2005). SG of the other species was obtained from literature, or estimated using SG values from species of the same genus (Table 1). However, no SG could be obtained for the palm species Attalea phalerata and Copernicia alba, and for the dicot species Campomanesia eugenioides, Ruprechtia sp., Tocoyena formosa, and Capparis spinosa. When SG of single species is not available, Baker et al. (2004) suggests the application of the stand-level average SG on the individuals of these species. Accordingly, we used the stand-level average SG of our study plots $\left(0.63 \mathrm{~g} / \mathrm{cm}^{3}\right)$ for these species.

\section{Results}

\section{Inundation}

Mean amplitude between lowest and highest water levels of the Ladário gauge, Paraguay River during the last 19 years amounted to $311.4 \pm 89.9 \mathrm{~cm}$. Assuming a linear dependence between the water levels of the Ladário gauge and the period of inundation at our study sites, the topographic lowest point in our plots was inundated for $74.1 \pm$ 58.5 days/year (14 inundations during the last 19 years, mean inundation height $65.2 \mathrm{~cm}$ ), whereas the topographic highest point was inundated for only $21.0 \pm$ 38.2 days/year (six inundations during the last 19 years, mean inundation height $18.5 \mathrm{~cm})$. The mean inundation length in our study plots thus amounts to $39.4 \pm$ 46.2 days/year, corresponding to a mean inundation height of $30.44 \pm 15.63 \mathrm{~cm}$ (Fig. 2).

\section{Floristic Composition and Species Diversity}

A total of 443 individuals, belonging to 26 families, 42 genera, and 46 species, were inventoried. The most important family was the Fabaceae (approximately $26 \%$ of all individuals), followed by the Bignoniaceae, Urticaceae, and Lauraceae (each with approximately $10 \%$ of all individuals). The four most important species accounted for $52.8 \%$ of the TIV (Inga vera, Cecropia pachystachya, Ocotea suaveolens, and Tabebuia heptaphylla), whereas 16 tree species were represented by only a single individual (Table 1).

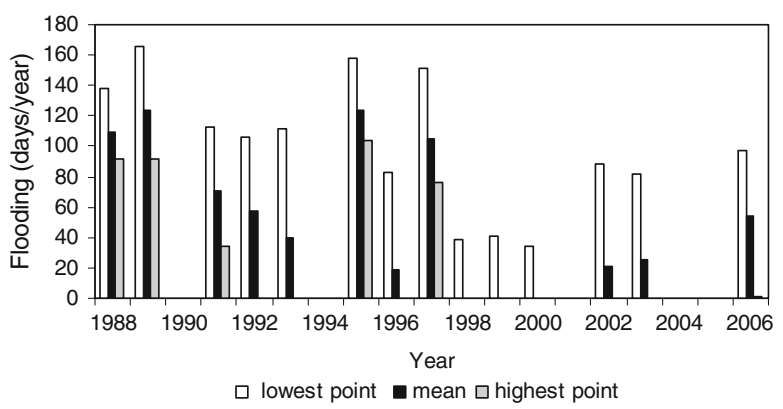

Fig. 2 Mean flooding period of trees in our study plots during 1988-2006, estimated from daily floodlevel data of the Ladário gauge, Paraguay River (DNAEE - Departamento Nacional de Águas e Energia Elétrica, Brazil) 
Within the 16 plots of our study, tree species richness varied between six and 13 species per plot $\left(625 \mathrm{~m}^{2}\right)$, and the species diversity between 0.75 and 2.17 (mean: $1.43 \pm$ 0.39 ). Floristic similarity between the plots averaged $38.25 \%$ (min: 8.33 ; max: 77.77).

\section{Floristic Patterns Along the Flooding Gradient}

We detected a significant correlation of increasing species diversity with decreasing period of flooding (Fig. 3). The MDC of the species, based on the variables flood height/period of waterlogging, and distance of individuals to the river bank indicated similar ecological requirements especially of the common species (Fig. 4). The mean period of waterlogging in these species ranged from 26.0 \pm 17.7 days/year (Vitex cymosa) to $42.7 \pm 10.8$ days/year (Pouteria glomerata), and the mean distance to the river bank from $6.6 \pm 4.6 \mathrm{~m}$ (Erythroxylum anguifugum) to $12.3 \pm 8.2 \mathrm{~m}$ (Alibertia edulis); the MDC of the most important species Inga vera, Cecropia pachystachya, Ocotea suaveolens, and Tabebuia heptaphylla was almost identical (Fig. 4). Differences in species distribution patterns thus were mainly restricted to the MDC of the rare species (Fig. 4).

\section{Forest Structure, Wood Specific Gravity, and Aboveground Wood Biomass}

The tree distribution by dbh-class showed a reverse $\mathrm{j}$-shaped curve, indicating that most individuals had diameters of 10-15 cm. The basal area per plot (BA) averaged $2.99 \pm 1.13 \mathrm{~m}^{2}$, corresponding to a total BA of $47.84 \pm 18.1 \mathrm{~m}^{2} / \mathrm{ha}$. Average tree height amounted to $10.86 \pm 1.37 \mathrm{~m}$, with most trees being characterized by heights below $10 \mathrm{~m}$ (Table 1). There was a strong exponential relationship between tree dbh and height of the common tree species (Fig. 5), but the significance was reduced when rare tree species were included in the analysis $\left(R^{2}=0.69, P=0.001\right)$.

The plot AWV averaged $24.45 \pm 11.75 \mathrm{~m}^{3}$, showing a strong correlation to the plot's basal areas $\left(R^{2}=0.88, P=0.001\right)$, whereas no significant relation was detected between AWV and tree heights $\left(R^{2}=0.188, P=0.52\right)$. Total AWV amounted to $391.14 \pm 188.05 \mathrm{~m}^{3} /$ ha. Although single species showed trends of increasing AWV with decreasing height/period of flooding (e.g., Tabebuia heptaphylla, $R^{2}=0.234$, $P=0.01$ ), there was no significant relationship between these variables and flooding when more or even all species were included in the analysis.

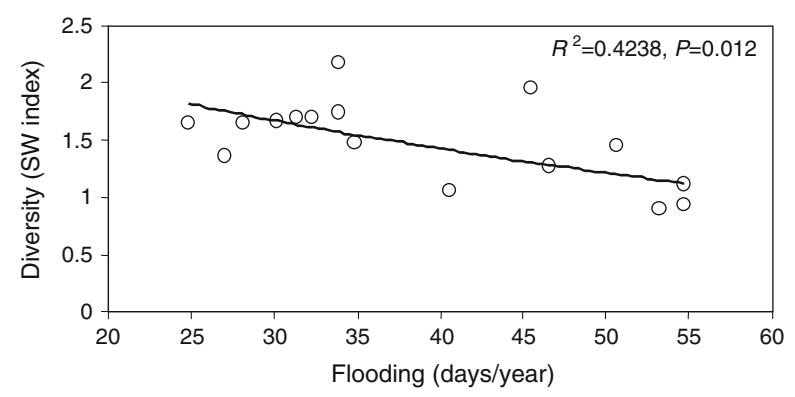

Fig. 3 Species diversity (Shannon and Weaver 1949) in the 16 study plots plotted against the mean flooded period 


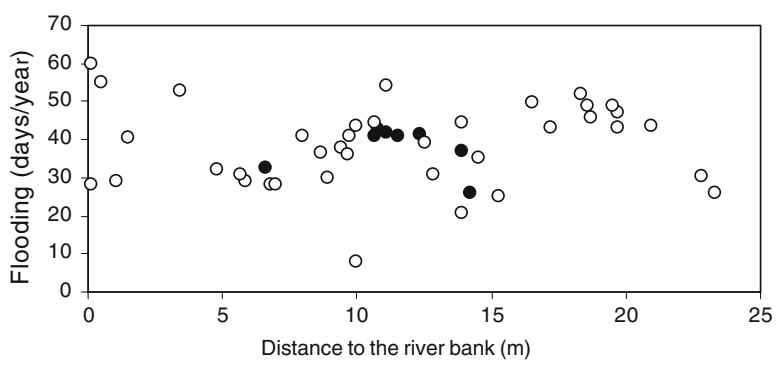

Fig. 4 Mean spatial distribution center (MDC, Ebdon 1998) of the tree species in the study plots based on the mean inundation period during the last 19 years and the distance of individuals to the river bank. Black circles - common tree species $(8$ species with $\geq 10$ individuals, $n=334)$, white circles - rare species $(38$ species with $<10$ individuals, $n=111$ )

Wood specific gravity in the 15 investigated species ranged from $0.39 \pm 0.03 \mathrm{~g} / \mathrm{cm}^{3}$ (Cecropia pachystachya) to $0.87 \pm 0.02 \mathrm{~g} / \mathrm{cm}^{3}$ (Tabebuia heptaphylla), and averaged $0.63 \pm 0.12 \mathrm{~g} / \mathrm{cm}^{3}$ (Table 1). AWB in our plots was highly variable, and averaged $16.22 \pm 6.38 \mathrm{Mg}$, totalling $259.45 \pm 102.02 \mathrm{Mg} / \mathrm{ha}$. Plot AWB correlated with AWV $\left(R^{2}=0.93, P=0.001\right)$, which basically could be traced back to the significant correlations between AWB and BA $\left(R^{2}=0.85, P=0.001\right)$, whereas no significant correlations existed between plot AWB and mean SG, plot AWB and tree heights, and plot AWB and the number of individuals present. Although we detected a slight increase of the plot AWB with decreasing impact of flooding, this trend was nonsignificant $\left(R^{2}=0.014, P=0.7\right)$.

\section{Discussion}

The Pantanal is one of the Neotropical floodplains subjected to a monomodal floodpulse (Junk et al. 1989). The flood pulse is a major driving force for species distribution and diversity, because it determines ecological processes and thus triggers the level of adaptation and species selection. The small-scale mosaic of alluvial and basin topography within the Pantanal creates sites from almost permanently waterlogged to rarely inundated, which is reflected by the vegetation cover (Silva et al. 2000; Nunes da Cunha and Junk 2001). The periodic inundations

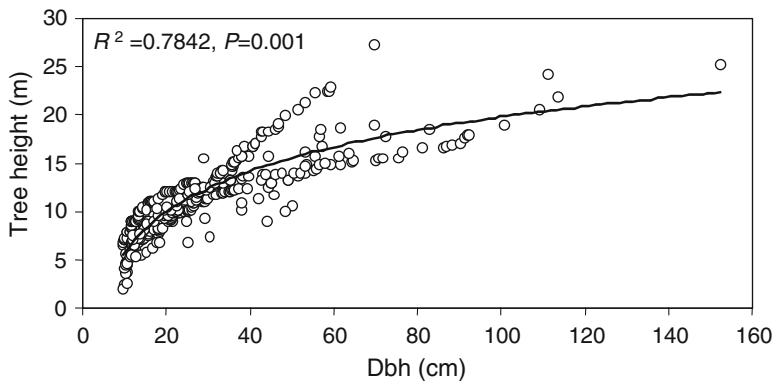

Fig. 5 Tree heights of common tree species ( 8 species with $\geq 10$ individuals, $n=334$ ) plotted against dbh 
and the related potential stressful conditions often lead to mono-dominant forests (Pott and Pott 1994), which are defined as forests where one species shows dominance of $\geq 50 \%$ (Connell and Lowman 1989).

The riparian forest investigated in our study is not mono-dominant sensu Connel and Lowman (1989), but is characterized by four almost evenly weighted species (Inga vera, Cecropia pachystachya, Ocotea suaveolens, and Tabebuia heptaphylla) that comprise more than $50 \%$ of the total importance. While I. vera, O. suaveolens, and T. heptaphylla were almost evenly distributed across the inventoried forest, C. pachystachya showed a strongly clumped distribution pattern with more than the half of its total of individuals being restricted to only one plot. It is well known that the genus Cecropia comprises pioneer species that often initiate secondary forest succession (Franco-Rosselli and Berg 1997). The high importance of C. pachystachya in our forest is thus probably the result of natural or anthropogenic disturbance (fire, deforestation) in the past in one of our plots, followed by secondary colonization by this species.

The other co-dominant species have almost similar ecological requirements. With regard to the topographical position occupied, the species undergo mean annual flooded periods of 40.9 (I. vera), 41.0 (O. suaveolens) and 41.6 (T. heptaphylla) days/year, thus occupying a very restricted spatial distribution along the flooding gradient. Flooding at these levels, however, varies extremely and can be between 0 (i.e., 1990, 1994, 1998-2001) and 123 days/year (1995).

Characteristic morpho-anatomical and/or physiological adaptations of tree species to flooding, such as they occur in many species of Amazonian floodplain forests (e.g., pneumatophores, adventitious roots, lenticels, and pronounced leaf shedding during periods of highest water levels) are unknown within tree species of the Pantanal. Junk et al. (2006) stated that there are no endemic tree species within the Pantanal, most species being immigrants from the adjacent Cerrado biome with a wide tolerance of periodic dry and wet conditions. The restricted distribution along the flooding gradient combined with highly variable inundation periods affects tree species at the population level, and probably defines tree establishment and distribution. There is some evidence that many tree species of flooded forests in both temperate zones (poly-modal flooding) and Amazonia (mono-modal flooding) depend on establishment in consecutive periods with exceptionally low inundations (Wittmann and Junk 2003; Schnitzler et al. 2005). We thus argue that the high flood variability in riparian forests of the Pantanal favours the dominance of a few tree species that regenerate during consecutive years with low water levels, and that are highly competitive especially during the early stages of life. The high variability of the inundation level of the Miranda River thus would explain the co-dominance of a few tree species in our riparian forest.

Tree species richness and diversity is linked to the flooding gradient, and is thus similar to other seasonal flooded Neotropical forests (Oliveira-Filho et al. 1994; Metzger et al. 1997; Wittmann et al. 2006a). The zonation of tree species along the flooding gradient is, however, less pronounced than in Amazonian floodplains, where it can occupy a vertical height of up to $9 \mathrm{~m}$ (Ferreira 1997). In the riparian forest of the present study, increasing diversity with decreasing impact of flooding is strongly linked to the presence of rare species that are represented by a single or few individuals. These species are tolerant of seasonal inundations, but not restricted to 
highly inundated habitats. This probably reflects the short period of floristic evolution and climatic instability within the Pantanal in the past in comparison to other Neotropical floodplains like the Amazon. The main period of subsidence resulting in the Pantanal wetland depression is related to the last compressional pulse of the Andes during the upper Plio- lower Pleistocene about 2.5 million years ago (Junk et al. 2006). In addition, climatic changes during the Quaternary led to intermittent periods of large-scale flooding and severe droughts (Ab'Saber 1988; Assine and Soares 2004). In comparison, it is thought that floodplain forests in the Amazon basin have persisted at least since the early Paleocene (Kubitzki 1989). Quaternary climatic changes affected these extensive floodplains to a comparatively low extent, whereas they interrupted evolutional processes in floodplains of the Pantanal. This would explain the absence of specifically flood-adapted tree species associations within the Pantanal.

The AWV and AWB in the riparian forest of the present study are comparable to those reported in late-successional inundation forests of the Amazon basin (between 206 and $382 \mathrm{Mg} / \mathrm{ha}$, Nebel et al. 2001; Schöngart 2003), and close to the worldwide tropical average AWB given by Clark et al. (2001) $(278 \mathrm{Mg} / \mathrm{ha})$. This is somewhat surprising when the structure of these forest types is compared. Depending on the topographic position along the flooding gradient, late-successional inundation forests in the Amazon basin are highly stratified, the upper canopy establishing at heights between 20-35 m (Worbes et al. 1992; Wittmann et al. 2002). Upper-canopy trees represent $58 \%-65 \%$ of the total aboveground wood biomass in these forests (Schöngart 2003). Mean tree height in the riparian forest of the Miranda River is only about one-half to one-third of that of Amazonian floodplain forests. High AWV and AWB in our forest is thus the result of comparatively high stand-level basal area. The high basal area in many of the tree species recorded was due to a high number of ramifications below breast height (i.e., in Alibertia edulis, Casearia decandra, Erythroxylon anguifugum, Eugenia florida and Triplaris americana). High resprouting tendencies in these species may be a response to the irregular flooding conditions. In Amazonian floodplain forests, Wittmann and Parolin (2005) reported the intense resprouting of highly inundated tree species of the genus Symmeria, Alchornea, Salix, and Buchenavia. Resprouting increases root and stem surfaces in these species and thus facilitates aeration during flooding (Lüttge 1997). In addition, it allows for the persistence of many shrubs and trees after catastrophic events such as fire (Matlack et al. 1993; Olson and Platt 1995; Cirne and Scarano 2001). It is thus possible that species originating from the adjacent Cerrado, and with high resprouting ability, have an important pre-adaptation that makes them competitive when establishing in seasonal flooded areas of the Pantanal.

AWB estimates of forest communities undergo different uncertainities, which include errors in height and dbh measurements especially in irregular-shaped trunks, intraindividual and intraspecific SG variations, and imprecisions of allometric models used for tree volume estimation (Chave et al. 2005). Because dbh generally is related to tree height, $\mathrm{AWV}$, and AWB, many biomass estimates in tropical forests are based on dbh measurements as single variable, and use stand-level SG estimates (Brown 1997; Clark et al. 2001; Baker et al. 2004; Mahli et al. 2006). Although the present study was not designed to investigate the possible error propagation of the different variables used in biomass estimates, we attempt to minimize uncertainities 
in our AWB approximate by the inclusion of exact tree height measurements, and SG determinations of the most important species. However, the comparatively high variations in forest structure and AWB between our plots demonstrate the difficulties in the assessment of confident stand-level AWB estimates. The riparian forest of the Miranda River is highly variable in both floristic composition and forest structure. Local hydraulic changes of the meandering river and the highly variable flood regime might be important factors contributing to the development of different riparian forest types, and to the small-scale AWB variations.

Acknowledgements This study was performed with Post-graduate students from the Ecology and Conservation course of the Federal University of Mato Grosso do Sul (UFMS), Campo Grande, Brazil. Field work was made possible by financial support from the UFMS. We wish to thank Wolfgang J. Junk and three unknown referees for valuable comments on the manuscript.

Open Access This article is distributed under the terms of the Creative Commons Attribution Noncommercial License which permits any noncommercial use, distribution, and reproduction in any medium, provided the original author(s) and source are credited.

\section{References}

Ab'Saber AN (1988) O Pantanal mato-grossense e a teoria dos refúgios (The Pantanal of Mato Grosso and the refugial hypothesis). Revista Brasil Geogr 50:9-57

Adámoli J (1986) A dinâmica das inundações no Pantanal (The dynamics of inundation within the Pantanal). In EMBRAPA (Empresa Brasileira de Pesquisa Agropecuária) (ed) Anais do I. Simpósio sobre recursos naturais e socio-econômicos do Pantanal. Embrapa Corumbá, pp 51-61

Assine ML, Soares PC (2004) Quaternary of the Pantanal, west-central Brazil. Quartern Int 114:23-34

Baker TR, Phillips OL, Malhi Y, Almeida S, Arroyo L, Di Fiore A, Killeen TJ, Laurance SG, Laurance WF, Lewis SL, Lloyd J, Monteagudo A, Neill DA, Patiño S, Pitman NCA, Silva N, VásquezMartínez R (2004) Variation in wood density determines spatial patterns in Amazonian forest biomass. Global Change Biol 10:545-562

Brown S (1997) Estimating biomass and biomass change of tropical forests: a primer. FAO Forestry Paper 134. FAO, Rome

Cannell MGR (1984) Woody biomass of forest stands. Forest Ecol Managem 8:299-312

Chave J, Andalo C, Brown S, Cairns MA, Chambers JQ, Eamus D, Fölster H, Fromard F, Higuchi N, Kira T, Lescure J-P, Nelson BW, Ogawa H, Puig H, Riéra B, Yamakura T (2005) Tree allometry and improved estimation of carbon stocks and balance in tropical forests. Oecologia 145:87-99

Cirne P, Scarano FR (2001) Resprouting and growth dynamics after fire of the clonal shrub Andira legalis (Leguminosae) in a sandy coastal plain in south-eastern Brazil. $J$ Ecol 89:351-357

Clark DA, Brown S, Kicklighter DW, Chambers JQ, Thomlinson JR, Ni J, Holland EA (2001) Net primary production in tropical forests: an evaluation and synthesis of existing field data. Ecol Appl 11:371-384

Connell JH, Lowman MD (1989) Low-density tropical rainforests: some possible mechanism for their existence. Amer Naturalist 134:88-119

Curtis JT, McIntosh RP (1951) An upland forest continuum in the prairie-forest border region of Wisconsin. Ecology 32:476-496

Damasceno Jr., GA, Semir J, Santos FAM, Leitao Filho HF (2005) Structure, distribution of species, and inundation in a riparian forest of Rio Paraguai, Pantanal, Brazil. Flora 200:119-135

Ebdon D (1998) Statistics in geography. Basil Blackwell, Oxford

Enquist BJ, West GB, Charnov EL, Brown JH (1999) Allometric scaling of production and life-history variation in vascular plants. Nature 401:907-911

Fearnside PM (1997) Wood density for estimating forest biomass in Brazilian Amazonia. Forest Ecol Managem 90:59-87

Fernandez MD, Pieters A, Donoso C, Herrera C, Tezara W, Rengifo E, Herrera A (1999) Seasonal changes in photosynthesis of trees in the flooded forest of the Mapire River. Tree Physiol 19:79-85 
Ferreira LV (1997) Effects of the duration of flooding on species richness and floristic composition in three hectares in the Jaú National Park in floodplain forests in central Amazonia. Biodiversity Conserv 6:1353-1363

Franco-Rosselli P, Berg CC (1997) Distributional patterns of Cecropia (Cecropiaceae): a panbiogeographic analysis. Caldasia 19:285-296

Godoy JR, Petts G, Salo J (1999) Riparian flooded forests of the Orinoco and Amazon basins: a comparative review. Biodiversity Conserv 8:551-586

Haase R, Haase P (1995) Above-gound biomass estimates for invasive trees and shrubs in the Pantanal of Mato Grosso, Brazil. Forest Ecol Managem 73:29-35

Hamilton S, Sippel S, Melack J (1996) Inundation patterns in the Pantanal wetland of South America determined from passive microwave remote sensing. Arch Hydrobiol 137:1-23

IBGE (ed) (1992) Manual técnico da vegetação brasileira (Technical manual of the vegetation of Brazil). Fundação Instituto Brasileiro de Geografia e Estatística - IBGE, Rio de Janeiro

Jackson MB, Colmer TD (2005) Response and adaptation by plants to flooding stress. Ann Bot (Oxford) 96:501-505

Joly CA (1991) Flooding tolerance in tropical trees. In Jackson MB, Davies DD, Lambers H (eds) Plant life under oxygen deprivation. Academic Publishing, The Hague, pp 23-34

Junk WJ, Bayley PB, Sparks RE (1989) The flood pulse concept in river-floodplain systems. Canad Spec Publ Fish Aquatic Sci 106:110-127

Junk WJ, Cunha CN, Wantzen KM, Petermann P, Strüssmann C, Marques MI, Adis J (2006) Biodiversity and its conservation in the Pantanal of Mato Grosso, Brazil. Aquat Sci 68:278-309

Kubitzki K (1989) The ecogeographical differentiation of Amazonian inundation forests. Pl Syst Evol 163:285-304

Lüttge U (1997) Physiological ecology of tropical plants. Springer Verlag, Berlin

Mahli Y, Wood D, Bakers TR, Wright J, Phillips OL, Cochrane T, Meir P, Chave J, Almeida S, Arroyo L, Higuchi N, Killeen TJ, Laurance SG, Laurance WF, Lewis SL, Monteagudo A, Neill DA, Vargas PN, Pitman NC, Quesada CA, Salomão R, Silva JNM, Lezama AT, Terborgh J, Martínez RV, Vinceti B (2006) The regional variation of aboveground life biomass in old-growth Amazonian forests. Global Change Biol 12:1-32

Matlack GR, Gibson DJ, Good RE (1993) Regeneration of the shrub Gaylussacia baccata and associated species after low intensity fire in the Atlantic coastal plain forest. Amer J Bot 80:119-126

Metzger JP, Bernacci LC, Goldenberg R (1997) Pattern of tree species diversity in riparian forest fragments of different widths. Pl Ecol 133:135-152

Nebel G, Kvist L, Vanclay JK, Christensen H, Freitas L, Ruíz J (2001) Structure and floristic composition of flood plain forests in the Peruvian Amazon I. Overstorey. Forest Ecol Managem 150:27-57

Nogueira EM, Nelson BW, Fearnside PM (2005) Wood density in dense forest in central Amazonia, Brazil. Forest Ecol Managem 208:261-286

Nunes da Cunha C, Junk WJ (2001) Distribution of woody plant communities along the flood gradient in the Pantanal of Poconé, Mato Grosso, Brazil. Int J Ecol Environm Sci 27:63-70

Oliveira-Filho AT, Vilela EA, Carvalho DA, Gavilanes ML (1994) Effects of soils and topography on the distribution of tree species in a tropical riverine forest in south-eastern Brazil. J Trop Ecol 10:483-508

Olson MS, Platt W (1995) Effects of habitat and growing season fires on resprouting of shrubs in longleaf pine savannas. Vegetatio 119:101-118

Parolin P, De Simone O, Haase K, Waldhoff D, Rottenberger S, Kuhn U, Kesselmeier J, Kleiss B, Schmidt W, Piedade MTF, Junk WJ (2004) Central Amazon floodplain forests: tree adaptation in a pulsing system. The Bot Rev 70:357-380

Pither R, Kellman M (2002) Tree species diversity in small tropical riparian forest fragments in Belize, Central America. Biodiversity Conserv 11:1623-1636

Pott A, Pott VJ (1994) Plantas do Pantanal (Plants of the Pantanal). Empresa Brasileira de Pesquisa Agropecuária (EMBRAPA), Corumbá

Prance GT, Schaller GB (1982) Preliminary study of some vegetation types of the Pantanal, Mato Grosso, Brazil. Brittonia 32:228-251

Salo J, Kalliola R, Häkkinen I, Mäkinen Y, Niemelä P, Puhakka M, Coley PD (1986) River dynamics and the diversity of the Amazon lowland forest. Nature 322:254-258

Sarmiento G, Monasterio M (1975) A critical consideration of the environmental conditions associated with the occurrence of savanna ecosystems in tropical America. In Golley FB, Medina E (eds) Tropical ecological systems. Springer, Berlin, pp. 223-250

Schnitzler A, Hale BW, Alsum E (2005) Biodiversity of floodplain forests in Europe and eastern North America: a comparative study of the Rhine and Mississippi valleys. Biodiversity Conserv 14:97-117 
Schöngart J (2003) Dendrochronologische Untersuchungen in Überschwemmungswäldern der várzea Zentralamazoniens. In Böhnel H, Tiessen H, Weidelt HJ (eds) Göttinger Beiträge zur Land- und Forstwirtschaft in den Tropen und Subtropen 149. Erich Goltze, Göttingen

Shannon CE, Weaver W (1949) The mathematical theory of communication. University Illinois Press, Urbana

Silva MP, Mauro R, Mourão G, Coutinho M (2000) Distribution and quantification of vegetation classes by aerial survey in the Brazilian Pantanal. Revista Brasil Bot 23:143-152

Sørensen T (1948) A method of establishing groups of equal amplitude in plant sociology based on similarity of species content and its application to analyses of the vegetation on Danish commons. Det Kongel Danske Vidensk Selsk Biol Skr 5:1-34

Terborgh J, Petren K (1991) Development of habitat structure through succession in an Amazonian floodplain forest. In Bell SS (ed) Habitat structure. Chapman and Hall, London, pp 28-46

Veneklaas EJ, Fajardo A, Obregon S, Lozano J (2005) Gallery forest types and their environmental correlates in a Colombian Savanna landscape. Ecography 28:236-252

Wittmann F, Junk WJ (2003) Sapling communities in Amazonian white-water forests. J Biogeogr 30:1533-1544

Wittmann F, Parolin P (2005) Aboveground roots in Amazonian floodplain trees. Biotropica 37:609-619

Wittmann F, Anhuf D, Junk WJ (2002) Tree species distribution and community structure of Central Amazonian várzea forests by remote sensing techniques. J Trop Ecol 18:805-820

Wittmann F, Schöngart J, Montero JC, Motzer T, Junk WJ, Piedade MTF, Queiroz HL, Worbes M (2006a) Tree species composition and diversity gradients in white-water forests across the Amazon basin. $J$ Biogeogr 33:1334-1347

Wittmann F, Schöngart J, Parolin P, Worbes M, Piedade MTF, Junk WJ (2006b) Wood specific gravity of trees in Amazonian white-water forests in relation to flooding. IAWA J 27:255-266

Wittmann F, Schöngart J, Brito JM de, Oliveira Wittmann A, Piedade MTF, Parolin P, Junk WJ, Guillaumet J-L (in press) Manual of trees in central Amazonian várzea floodplains: taxonomy, ecology, and use. Edition Valer, Manaus

Worbes M (1997) The forest ecosystem of the floodplains. In Junk WJ (ed) The Central Amazon floodplains. Ecology of a pulsing system. Springer Verlag Berlin, Heidelberg, New York, pp 223-266

Worbes M, Klinge H, Revilla JD, Martius C (1992) On the dynamics, floristic subdivision and geographical distribution of várzea forests in Central Amazonia. J Veg Sci 3:553-564

Zeilhofer P, Schessl M (1999) Relationship between vegetation and environmental conditions in the northern Pantanal of Mato Grosso, Brazil. J Biogeogr 27:159-168

Received: 3 September 2007 / Revised: 29 April 2008 / Accepted: 29 April 2008 /

Published online: 2 December 2008 